\begin{tabular}{|l|l|l||}
\hline \multicolumn{2}{|c|}{ PublisherInfo } \\
\hline \hline PublisherName & $:$ & BioMed Central \\
\hline \hline PublisherLocation & $:$ & London \\
\hline \hline PublisherImprintName & $:$ & BioMed Central \\
\hline \hline
\end{tabular}

\title{
Complement factor H deficiency and atypical HUS
}

\begin{tabular}{|l|l|l||}
\hline \multicolumn{2}{|c||}{ ArticleInfo } \\
\hline \hline ArticleID & $:$ & 16 \\
\hline \hline ArticleDOI & $:$ & $10.1186 /$ ar-2000-66767 \\
\hline \hline ArticleCitationID & $:$ & 66767 \\
\hline \hline ArticleSequenceNumber & $:$ & 12 \\
\hline \hline ArticleCategory & $:$ & Paper Report \\
\hline \hline ArticleFirstPage & $:$ & 1 \\
\hline \hline ArticleLastPage & $:$ & 3 \\
\hline \hline & & RegistrationDate : 2000-1-4 \\
ArticleHistory & $:$ & OnlineDate \\
\hline \hline ArticleCopyright & $:$ & Current Science Ltd2000-4 \\
\hline \hline ArticleGrants & $:$ & \\
\hline \hline ArticleContext & $:$ & 130752211 \\
\hline \hline
\end{tabular}




\section{Keywords}

Atypical haemolytic uraemic syndrome, complement deficiency, genes, linkage

\section{Context}

Haemolytic-uraemic syndrome (HUS) is a clinically heterogeneous disease which comprises renal failure, microangiopathic haemolysis and thrombocytopenia. The majority of cases occur in children in an epidemic fashion and are associated with prodromal diarrhoea (an E. coli verotoxin has been implicated in some cases). HUS may also occur sporadically, in older children and adults in which genetic factors appear to operate. Both recessive and dominant modes of inheritance have been described in this form of atypical HUS. There is a continuous spectrum between atypical HUS and thrombotic thrombocytopenic purpura (TTP). Low levels of complement C3 and hypocomplementaemia have been documented in atypical HUS and recently several families with low levels of serum complement factor $\mathrm{H}(\mathrm{CFH})$ have been described. $\mathrm{CFH}$ is a regulatory protein that inhibits the formation and action of $\mathrm{C} 3$ convertase. Structurally, CFH consists of a string of 20 short consensus repeats (SCRs). One effect of CFH deficiency is consumptive depletion of C3. Clinical consequences of CFH deficiency include recurrent pyogenic infections, lupus-like disease and membranoproliferative glomerulonephritis. To examine a large single pedigree (Bedouin) for linkage using microsatellite markers in the vicinity of the $\mathrm{CFH}$ locus on human chromosome 1.

\section{Significant findings}

All affected individuals exhibited hypocomplementaemia during attacks and in remission. Linkage was demonstrated between atypical HUS and several markers on 1q32. Maximum linkage was observed at D1S1175. In view of these data, CFH represents a good candidate gene and was examined for sequence variation by SSCP. A transition in the last (20th) exon was identified resulting in a nonconservative S1191L substitution. This mutation was homozygous in all affected family members. The variant was not detected in a control sample of 96 people. By western blotting and pulse-chase analysis, it was shown that a similar amount of wild type and mutant factor $\mathrm{H}$ was synthesised by fibroblast cells. No CFH was detected in the serum of patients.

\section{Comments}


The authors provide good evidence for linkage between CFH and a recessive atypical HUS in a Bedouin kindred. The work nicely details how a transition in SCR 20 was identified and explores how the molecular lesion might interfere with CFH function. Although no definite conclusion was reached, a protein stability disturbance is the most likely explanation based on the evidence provided. One of the most interesting questions raised by this paper is how a mutation in CFH would produce the HUS phenotype. Since current treatments for atypical HUS (and the related TTP) are limited, better understanding of disease mechanism is very important. It is apparent that several mutations in CFH have been identified. Why the phenotypic consequence of these lesions should be so varied is not known. The particular association of CFH deficiency with HUS (compared with C3 or factor I deficiency) raises the possibility that CFH posseses additional, unknown actions. Of note, is a CFH mutation that occurred in Norwegian Yorkshire pigs that resulted in a mesangiocapillary glomerulonephritis. It is most likely that the clinical phenotype of a CFH lesion is influenced by other genes.

\section{Methods}

A single pedigree of VII generations was studied, comprising 35 individuals at VI and VII, of whom 11 were affected with atypical HUS. The affected individuals were offspring from five marriages, all of which were consanguineous. Family members were genotyped using fifteen markers in the region of $\mathrm{CFH}$ on chromosome 1q32. Linkage analysis was performed using a parametric model, assuming recessive inheritance and complete penetrance. The $\mathrm{CFH}$ gene was screened for mutations using single strand conformation polymorphism (SSCP); the coding sequence was analysed using exonic primers. The production of CFH by fibroblasts was studied by western blotting and also by pulse-chase with $\left[\mathrm{S}^{35}\right]$-methionine followed by immunoprecipitation.

\section{References}

1. Ying L, Katz Y, Schlesinger M, Carmi R, Shalev H, Haider N, Beck G, Sheffield VC, Landau D: Complement factor $\mathrm{H}$ gene mutation associated with autosomal recessive atypical hemolytic uremic syndrome. Am J Hum Genet. 2000, 65: 3168-3178.

This PDF file was created after publication. 